\title{
A novel, highly divergent ssDNA virus identified in Brazil infecting apple, pear and grapevine
}

\author{
Marcos Fernando Basso ${ }^{a, b}$, José Cleydson Ferreira da Silva ${ }^{b, c}$, \\ Thor Vinícius Martins Fajardo ${ }^{\mathrm{d}}$, Elizabeth Pacheco Batista Fontes ${ }^{\mathrm{b}, \mathrm{e}}$, \\ Francisco Murilo Zerbini ${ }^{a, b, *}$ \\ a Departamento de Fitopatologia, Universidade Federal de Viçosa, Viçosa, MG 36570-900, Brazil \\ b National Research Institute for Plant-Pest Interactions (INCT-IPP), Universidade Federal de Viçosa, Viçosa, MG 36570-900, Brazil

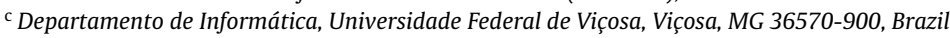 \\ d Embrapa Uva e Vinho, Bento Gonçalves, RS 95700-000, Brazil \\ e Departamento de Bioquímica e Biologia Molecular, Universidade Federal de Viçosa, Viçosa, MG 36570-900, Brazil
}

\section{A R T I C L E I N F O}

\section{Article history:}

Received 13 April 2015

Received in revised form 2 July 2015

Accepted 3 July 2015

Available online 14 July 2015

\section{Keywords:}

ssDNA viruses

Emerging viruses

Novel viruses

\begin{abstract}
A B S T R A C T
Fruit trees of temperate and tropical climates are of great economical importance worldwide and several viruses have been reported affecting their productivity and longevity. Fruit trees of different Brazilian regions displaying virus-like symptoms were evaluated for infection by circular DNA viruses. Seventyfour fruit trees were sampled and a novel, highly divergent, monopartite circular ssDNA virus was cloned from apple, pear and grapevine trees. Forty-five complete viral genomes were sequenced, with a size of approx. $3.4 \mathrm{~kb}$ and organized into five ORFs. Deduced amino acid sequences showed identities in the range of $38 \%$ with unclassified circular ssDNA viruses, nanoviruses and alphasatellites (putative Replication-associated protein, Rep), and begomo-, curto- and mastreviruses (putative coat protein, CP, and movement protein, MP). A large intergenic region contains a short palindromic sequence capable of forming a hairpin-like structure with the loop sequence TAGTATTAC, identical to the conserved nonanucleotide of circoviruses, nanoviruses and alphasatellites. Recombination events were not detected and phylogenetic analysis showed a relationship with circo-, nano- and geminiviruses. PCR confirmed the presence of this novel ssDNA virus in field plants. Infectivity tests using the cloned viral genome confirmed its ability to infect apple and pear tree seedlings, but not Nicotiana benthamiana. The name "Temperate fruit decay-associated virus" (TFDaV) is proposed for this novel virus.
\end{abstract}

(c) 2015 Elsevier B.V. All rights reserved.

\section{Introduction}

Fruit trees of temperate and tropical climates are of great economical importance worldwide. They are susceptible to several arthropod- and graft-transmitted agents that cause several diseases, some of which are aetiologically unknown. Vegetative propagation contributes to the spread of these pathogens, favoring the emergence of complex diseases (Al-Rwahnih et al., 2009; Hadidi and Barba, 2011; Martelli, 2012). The frequent exchange of propagative material between nurseries worldwide has contributed to their dissemination into new areas. The perennial life cycle of fruit trees also contributes to further accelerate the mixing and introduc-

\footnotetext{
* Corresponding author at: Departamento de Fitopatologia, Universidade Federal de Viçosa, Viçosa, MG 36570-900, Brazil. Fax: +55 3138992240.

E-mail address: zerbini@ufv.br (F.M. Zerbini).
}

tion of many viruses and subviral agents into a single plant (Hadidi and Barba, 2011; Rowhani et al., 2005).

Single-stranded (ss) DNA viruses represent a group of economically important plant pathogens. They are predisposed to recombination events and can present high nucleotide (nt) substitution rates, which contribute to their emergence (Lefeuvre et al., 2009; Martin et al., 2011). A method that has been used successfully for the detection of ssDNA viruses is rolling-circle amplification (RCA) (Inoue-Nagata et al., 2004). Due to its sequence-unbiased nature, this method has allowed the identification of several new ssDNA viral agents in different plant species.

In Brazilian apple and pear orchards and vineyards, symptoms of possible viral origin are frequently observed (Basso et al., 2014). With the objective of prospecting ssDNA viruses associated with these three hosts, samples displaying virus-like symptoms were collected at different regions of the country and were evaluated by PCR and RCA. We report here the cloning and molecular character- 
Table 1

Fruit tree samples displaying virus-like symptoms collected at different Brazilian regions and evaluated for the presence of ssDNA viruses.

\begin{tabular}{|c|c|c|c|}
\hline Samples & Collection date & Sampled plants/RCA-positive plants & Location \\
\hline Nectarine cv. Centenária & Oct-2012 & $2 / 0$ & UFV $^{c}$, Viçosa, MG \\
\hline Peach cv. Chiripá & Oct-2012 & $2 / 0$ & UFV, Viçosa, MG \\
\hline Acerola (cv. n.d.) ${ }^{a}$ & Nov-2012 & $1 / 0$ & UFV, Viçosa, MG \\
\hline Apple cv. Eva & Nov-2012 & $3 / 1$ & UFV, Viçosa, MG \\
\hline Lemon cv. Taiti & Nov-2012 & $1 / 0$ & UFV, Viçosa, MG \\
\hline Orange cv. Navelate & Nov-2012 & $1 / 0$ & UFV, Viçosa, MG \\
\hline Pear cv. Pera díágua & Nov-2012 & $3 / 1$ & UFV, Viçosa, MG \\
\hline Jabuticaba (cv. n.d.) & Dec-2012 & $1 / 0$ & UFV, Viçosa, MG \\
\hline Mango cv. Tommy Atkins & Dec-2012 & $1 / 0$ & UFV, Viçosa, MG \\
\hline Passion fruit (cv. n.d.) & Dec-2012 & $1 / 0$ & UFV, Viçosa, MG \\
\hline Apple cv. Fuji & Jan-2013 & $2 / 0$ & Linha Aparecida, Videira, SC \\
\hline Grapevine Muscadine (V. rotundifolia) & Jan-2013 & $1 / 0$ & UFV, Viçosa, MG \\
\hline Grapevine rootstock VR-043-43 & Jan-2013 & $2 / 0$ & UFV, Viçosa, MG \\
\hline Papaya (cv. n.d.) & Jan-2013 & $1 / 0$ & UFV, Viçosa, MG \\
\hline Apple (cv. n.d.) & Feb-2013 & $3 / 0$ & UFV, Viçosa, MG \\
\hline Guava (cv. n.d.) & Feb-2013 & $1 / 0$ & UFV, Viçosa, MG \\
\hline Grapevine cv. Alicante Bouschet (acc. 1) ${ }^{\mathrm{b}}$ & Mar-2013 & $1 / 0$ & Embrapa Uva e Vinho, Bento Gonçalves, RS \\
\hline Grapevine cv. Alicante Bouschet (acc. 2) & Mar-2013 & $1 / 0$ & Embrapa Uva e Vinho, Bento Gonçalves, RS \\
\hline Grapevine cv. Ancellotta ${ }^{\mathrm{b}}$ & Mar-2013 & $1 / 0$ & Embrapa Uva e Vinho, Bento Gonçalves, RS \\
\hline Grapevine cv. Cabernet Franc (acc. 1$)^{\mathrm{b}}$ & Mar-2013 & $1 / 0$ & Embrapa Uva e Vinho, Bento Gonçalves, RS \\
\hline Grapevine cv. Cabernet Franc (acc. 2) ${ }^{b}$ & Mar-2013 & $1 / 0$ & Embrapa Uva e Vinho, Bento Gonçalves, RS \\
\hline Grapevine cv. Cabernet Franc $(\mathrm{acc} .3)^{\mathrm{b}}$ & Mar-2013 & $1 / 0$ & Embrapa Uva e Vinho, Bento Gonçalves, RS \\
\hline Grapevine cv. Cabernet Sauvignon ${ }^{\mathrm{b}}$ & Mar-2013 & $1 / 0$ & Embrapa Uva e Vinho, Bento Gonçalves, RS \\
\hline Grapevine cv. Cannonau ${ }^{\mathrm{b}}$ & Mar-2013 & $1 / 1$ & Embrapa Uva e Vinho, Bento Gonçalves, RS \\
\hline Grapevine cv. Chardonnay (acc. 1$)^{\mathrm{b}}$ & Mar-2013 & $1 / 0$ & Embrapa Uva e Vinho, Bento Gonçalves, RS \\
\hline Grapevine cv. Chardonnay (acc. 2) & Mar-2013 & $1 / 0$ & Embrapa Uva e Vinho, Bento Gonçalves, RS \\
\hline Grapevine cv. Carmenère ${ }^{\mathrm{b}}$ & Mar-2013 & $1 / 0$ & Embrapa Uva e Vinho, Bento Gonçalves, RS \\
\hline Grapevine cv. Don Marino ${ }^{\mathrm{b}}$ & Mar-2013 & $1 / 0$ & Embrapa Uva e Vinho, Bento Gonçalves, RS \\
\hline Grapevine cv. Garganega (acc. 1$)^{\mathrm{b}}$ & Mar-2013 & $1 / 0$ & Embrapa Uva e Vinho, Bento Gonçalves, RS \\
\hline Grapevine cv. Garganega (acc. 2) & Mar-2013 & $1 / 0$ & Embrapa Uva e Vinho, Bento Gonçalves, RS \\
\hline Grapevine cv. Italia (VCR10) ${ }^{\mathrm{b}}$ & Mar-2013 & $1 / 0$ & Embrapa Uva e Vinho, Bento Gonçalves, RS \\
\hline Grapevine cv. Malvasia di Candia Aromatica ${ }^{\mathrm{b}}$ & Mar-2013 & $1 / 0$ & Embrapa Uva e Vinho, Bento Gonçalves, RS \\
\hline Grapevine cv. Merlot ${ }^{\mathrm{b}}$ & Mar-2013 & $1 / 0$ & Embrapa Uva e Vinho, Bento Gonçalves, RS \\
\hline Grapevine cv. Michele Palieri ${ }^{\mathrm{b}}$ & Mar-2013 & $1 / 0$ & Embrapa Uva e Vinho, Bento Gonçalves, RS \\
\hline Grapevine cv. Primitivo ${ }^{\mathrm{b}}$ & Mar-2013 & $1 / 0$ & Embrapa Uva e Vinho, Bento Gonçalves, RS \\
\hline Grapevine cv. Prosecco (acc. 1$)^{b}$ & Mar-2013 & $1 / 0$ & Embrapa Uva e Vinho, Bento Gonçalves, RS \\
\hline Grapevine cv. Prosecco (acc. 2$)^{b}$ & Mar-2013 & $1 / 0$ & Embrapa Uva e Vinho, Bento Gonçalves, RS \\
\hline Grapevine cv. Regina ${ }^{\mathrm{b}}$ & Mar-2013 & $1 / 0$ & Embrapa Uva e Vinho, Bento Gonçalves, RS \\
\hline Grapevine cv. Sangiovese ${ }^{b}$ & Mar-2013 & $1 / 0$ & Embrapa Uva e Vinho, Bento Gonçalves, RS \\
\hline Grapevine cv. Victoria ${ }^{\mathrm{b}}$ & Mar-2013 & $1 / 0$ & Embrapa Uva e Vinho, Bento Gonçalves, RS \\
\hline Avocado cv. Margarida & Mar-2013 & $1 / 0$ & Grupo Tsuge, São Gotardo, MG \\
\hline Pear cv. Pera díágua & Apr-2013 & $13 / 1$ & UFV, Viçosa, MG \\
\hline Apple cv. Eva & Apr-2013 & $7 / 0$ & UFV, Viçosa, MG \\
\hline Apple (cv. n.d.) & Apr-2013 & $3 / 0$ & UFV, Viçosa, MG \\
\hline
\end{tabular}

a cv. n.d.: cultivar not determined.

b Germplasm collection maintained in quarantine greenhouse.

c UFV: Universidade Federal de Viçosa; MG: state of Minas Gerais; RS: state of Rio Grande do Sul; SC: state of Santa Catarina.

ization of a novel, highly divergent, monopartite circular ssDNA virus of approx. $3.4 \mathrm{~kb}$ in length, with characteristics similar to members of the Circo-, Nano- and Geminiviridae families. The name "Temperate fruit decay-associated virus" (TFDaV) is proposed for this new virus.

\section{Materials and methods}

\subsection{Plant sampling}

Apple, pear and grapevine samples (adult plants over two years old) displaying virus-like symptoms such as chlorotic dwarf, delay and weakening of budding and dry branches (apple and pear; Suppl. Fig. S1) and shrinkage, reddening or red blistering of leaves (grapevine; Suppl. Fig. S1) were collected in different Brazilian regions (Table 1). Initially, 51 samples were evaluated. Later, an additional 10 apple and 13 pear samples were collected in the same orchard where positive samples were found (Viçosa, MG) to estimate the incidence of TFDaV.

\subsection{DNA extraction, viral genome amplification, cloning and sequencing}

Total nucleic acids were isolated from leafy or woody tissue according to Lodhi et al. (1994). A preliminary evaluation to detect begomoviruses was performed using PCR with degenerate primers for the DNA-A (PAL1v1978 and PAR1C496) and DNA-B (PBL1v2040 and PCRc1) (Rojas et al., 1993; all primers used in this work are described in Suppl. Table S1). Circular DNAs were amplified by RCA as described by Inoue-Nagata et al. (2004). RCA products were screened with different restriction enzymes and the generated fragments were excised from agarose gels, purified, cloned into a pBluescript vector (pKS, Stratagene) and sequenced at Macrogen (Seoul, South Korea). 


\subsection{Sequence analyses}

Viral genomes were assembled using DNA Baser Sequence Assembler v3.x software (www.DnaBaser.com). The resulting contigs were screened for sequence homologies using BLAST algorithms (Altschul et al., 1990). Open reading frames (ORFs) were predicted using ORF Finder (www.ncbi.nlm.nih.gov/projects/gorf/ ). Conserved domains of predicted ORFs were detected using NCBI's Conserved Domain Database (NCBI) (Marchler-Bauer et al., 2011), TMHMM (Moller et al., 2001) and SMART softwares (Letunic et al., 2012). Importin $\alpha$-dependent nuclear localization signals and DNA and RNA binding residues in the coat protein $(\mathrm{CP})$ deduced amino acid (aa) sequence were scanned, respectively, using cNLS Mapper (Kosugi et al., 2009) and BindN softwares (Wang and Brown, 2006). Multiple sequences alignments were performed using MEGA 6 (Tamura et al., 2013). Pairwise identity score distribution analyses of the replication-associated protein (Rep) and CP amino acids sequences were performed using Sequence Demarcation Tool(SDT) v. 1.2 (Muhire et al., 2014).

\subsection{Phylogenetic and recombination analysis}

Phylogenetic relationships of TFDaV isolates with viruses from major gemini-, nano-, circovirus and alphasatellite lineages (Suppl. Table S2) were analyzed based on Rep and CP amino acid sequences. For each sequence set, we used MUSCLE v. 3.8.31 (Edgar, 2004) to generate a multiple sequence alignment. Midpoint-rooted phylogenetic trees were constructed using Bayesian inference with MrBayes v. 3.2 (Ronquist and Huelsenbeck, 2003) $($ MCMC nruns =2, nchains $=2$, ngen $=10.000 .000$ generations, burn-in $=2500$ samples, samplefreq $=1000$, diagnfreq $=5000$, printfreq $=1000)$ and a mixed amino acid substitution model (prset aamodel $=$ mixed and BLOSUM as best-fit model). Trees were visualized using the FigTree v. 1.4.2 (tree.bio.ed.ac.uk/software/) and edited using Inkscape v. 0.91 .

Recombination events were searched within the TFDaV genome or in the Rep, CP and movement protein (MP) genes, using three distinct data sets: (i) complete genome sequences representing the major lineages of gemini-, nano- and circoviruses; (ii) all Rep sequences deposited in GenBank corresponding to nanoviruses and alphasatellites; and (iii) all CP and MP sequences deposited in GenBank corresponding to mastre-, curto- and begomoviruses (Suppl. Table S2). The analysis was performed with LDhat v. 2.2 (McVean et al., 2002) and RDP4 softwares (Martin et al., 2010).

\subsection{PCR-mediated detection of TFDaV}

New fresh samples from the original apple, pear and grapevine plants were collected to validate PCR-mediated detection of TFDaV. In addition, 10 apple and 13 pear symptomless samples were collected in the same orchard where infected plants were found (Viçosa, MG) and were evaluated by PCR. PCR with TFDaV-specific $\mathrm{CP}$ primers (Suppl. Table S1) was performed using the parameters described by (Basso et al., 2010). PCR amplicons of the expected size were purified, cloned into the pGEM-T Easy vector (Promega) and sequenced commercially (Macrogen). One of the TFDaV-infected pear trees (pear \#2) was also evaluated by RCA followed by SpeI restriction analysis. The amplified and SpeI-linearized viral genome was cloned and sequenced.

\subsection{Infectivity assay}

Plants of Nicotiana benthamiana, apple cvs. Gala and Fuji and pear cv. Max Red Bartlett (10-12 days after emergence) were biolistically-inoculated with the SpeI-linearized and recircularized TFDaV genome (GenBank access \# KJ955447), as described by
Aragão et al. (1996). Negative controls were mock-inoculated with the empty pKS vector. Inoculation was targeted to the cotyledons and to the first true leaf of apple and pear seedlings. After the development of the second or third true leaves, the inoculated plants were transplanted to soil and maintained in a greenhouse.

TFDaV systemic infection was evaluated by PCR using specific primers and by RCA followed by SpeI digestion, as described above. Samples consisted of young leaves collected at time 0 (immediately before inoculation) and at 45 and 90 days post-inoculation (dpi). PCR and RCA/SpeI-digested products of the expected sizes were purified and cloned, respectively, into the pGEM-T and pKS vectors, and sequenced. Total DNA from apple \#4 (cv. Gala) was diluted 1:25 $(\mathrm{v} / \mathrm{v})$ and used as a template for a new round of RCA/SpeI digestion.

\subsection{RNA silencing suppression assay}

Silencing suppression assays were performed as described previously (Johansen and Carrington, 2001) by infiltration of Agrobacterium tumefaciens cultures carrying the constructs pK7WG2:GFP (expressing the reporter protein GFP), the pK7WG2:HC-Pro-PVY (expressing the known suppressor HC-Pro, as a positive control) and pK7WG2 with inserts corresponding to the complete coding regions of the $\mathrm{CP}$ and MP. Negative controls were agroinfiltrated with the pK7WG2:GFP construct only. GFP fluorescence was monitored under UV and leaves were photographed from 3 days to 8 days post-infiltration using a Nikon D1X digital camera.

\section{Results}

\subsection{Fruit trees showing virus-like symptoms in the field were infected by a novel ssDNA virus}

All 51 samples of different fruit trees showing virus-like symptoms were PCR-negative for the presence of begomovirus using degenerate primers (data not shown). These samples were then evaluated by RCA followed by screening with different restriction enzymes. One apple tree (cv. Eva), one pear tree (cv. Pera d'água, referred to as pear \#1) and one grapevine (cv. Cannonau) yielded 3.0 and $3.4 \mathrm{~kb}$ fragments following digestion of the RCA product with SpeI (Suppl. Fig. S2A). Both fragments were excised from the gel, purified, cloned and sequenced. The $3.0 \mathrm{~kb}$ fragment corresponded to plant DNA (data not shown). The sequence of the $3.4 \mathrm{~kb}$ fragments from all three samples displayed identity with ssDNA viruses, and conserved domains of Rep, CP and MP from ssDNA viruses were identified in the deduced amino acid sequences of the ORFs (Suppl. Table S3). These results were confirmed with newly collected samples from the same three plants.

PCR assays further confirmed the presence of TFDaV in the original apple, pear and grapevine plants (Suppl. Fig. S2B). Out of the 23 additional samples collected (10 apple, 13 pear), one young pear tree (referred to as pear \#2) was PCR- and RCA-positive (Table 1; Suppl. Fig. S2B).

\subsection{Molecular features of the ssDNA virus detected in apple, pear and grapevine}

Forty-five complete viral genomes were sequenced from the four RCA-positive plants: 17 from apple, 18 from pear \#1, eight from pear \#2, and two from grapevine. Sequence analysis revealed a genome size of 3424-3442 nts, containing the conserved nonanucleotide TAGTATTAC (which is also present in the genomes of nanoviruses, circoviruses and alphasatellites) positioned within an intergenic region containing a short palindromic sequence capable of forming a stem-loop structure (Fig. 1A). Three iteron-like, tandem repeat sequences (putative binding sites of the Rep protein) are present in the intergenic region upstream of the stem-loop 


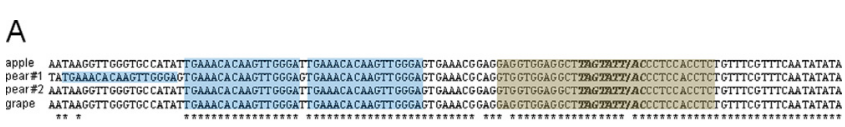

B

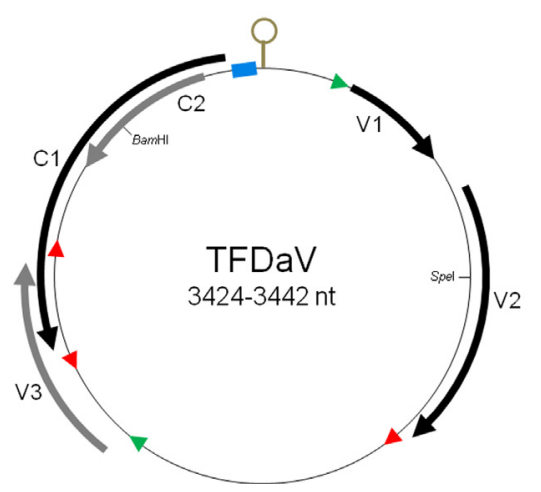

Fig. 1. Genomic features of temperate fruit decay-associated virus (TFDaV). A. Nucleotide sequence alignment of the region comprising the putative origin of replication. The sequence forming the stem-loop structure containing the conserved nonanucleotide (in bold italics) is higlighted in grey. Iteron-like sequences which may function as Rep binding sites to promote rolling-circle replication are highlighted in blue. B. Genomic organization of TFDaV indicating the five predicted ORFs (black and grey arrows), the stem-loop structure, the iteron-like sequences (blue rectangle), promoter regions (green arrowheads) and polyadenylation signals (red arrowheads). V1, movement protein (MP, nt 223-456); V2, coat protein (CP, nt 590-1303); V3, nt 2229-2663; C1, replication-associated protein (Rep, nt 2430-3374); C2, nt 2921-3310. Nucleotide coordinates refer to the apple isolate (KJ955447).

structure (Fig. 1A). Sequence comparisons among TFDaV isolates indicated that the isolates from pear \#1 had either a 35-nucleotide deletion in the intergenic region or an 18-nucleotide insertion upstream of the stem-loop structure (data not shown). Nevertheless, sequence identity amongst the 45 clones was greater than 99\% (Suppl. Fig. S3) and all subsequent analyses were performed with four clones: one from apple (KJ955447), one from pear \#1 (KJ955450), one from pear \#2 (KJ955451) and one from grapevine (KJ955449).

Predicted ORFs in the viral-sense strand potentially encode the MP, CP and a protein with no significant identity with other proteins in the databases (Fig. 1B; Suppl. Table S3). Two ORFs predicted in the complementary-sense strand potentially encode Rep and a protein with no significant identity with other proteins in the databases (Fig. 1B; Suppl. Table S3). The deduced amino acid sequence of the Rep protein has maximum identities of $38 \%$ with the homologous protein of circular ssDNA viruses isolated from sewage and sea water samples, 35\% with Malvastrum yellow mosaic alphasatellite and 34\% with black medic leafroll virus and faba bean necrotic stunt virus (gen. Nanovirus, fam. Nanoviridae) (Suppl. Table S3). For the CP-like protein, maximum identities are $29 \%$ with the CPs of the mastreviruses chickpea yellow dwarf virus and $28 \%$ with tobacco yellow dwarf virus, and for the MP-like protein it is $36 \%$ with the MP of the mastrevirus wheat dwarf India virus (Suppl. Table S3). A transmembrane domain was predicted in the aa sequences of the MP, which perfectly overlaps with the ones present in the MPs of nano- and mastreviruses (Suppl. Fig. S4). An importin $\alpha$-dependent nuclear localization signal and DNA-binding properties were predicted in the deduced aa sequence of the $\mathrm{CP}$ (Suppl. Fig. S5). Analysis of the deduced aa sequence of the putative Rep protein revealed the presence of conserved motifs such as Motif I (virus-specific dsDNA binding), Motif II (metal-binding site), Motif III (catalytic site for DNA cleavage), Walker A and B boxes (NTP binding) and DNA helicase (Suppl. Fig. S6). These motifs are similar to the ones present in the Rep proteins from circo-, nano- and geminiviruses. In addition, the sequences LEEGE and KEETRVSGPYTYG could functionally represent the LxCXE and KEEALQIIREKIP motifs found in the geminivirus tomato golden mosaic virus (TGMV) Rep, and which are involved in binding to the plant retinoblastoma protein $(\mathrm{pRb})$ (Suppl. Fig. S6).

Three putative transcription regulatory sequences were predicted in the TFDaV genome, one located upstream of the Rep and stem-loop structure, one positioned upstream of the CP and MP, and another upstream of the V3 ORF (Fig. 1B, blue and green markers). Three polyadenylation signals were also predicted downstream of the CP, V3 and Rep ORFs (Fig. 1B, red arrowheads).

\subsection{Recombination and phylogenetic analyses}

No recombination events were detected in the TFDaV sequence, independently of the data set used for the analysis (data not shown).

The phylogenetic trees based on the deduced aa sequences of the Rep and CP indicated that TFDaV isolates are located in a monophyletic clade, distinct from all other ssDNA viruses and subviral agents (Fig. 2). A tree based only on the conserved motifs I, II and III and the Walker A and B domains of the Rep protein displayed the same topology (data not shown).

The absence of DNA sequences with significant identities (Rep and $\mathrm{CP}$ pairwise identity score distribution of no more than $38 \%$; Suppl. Fig. S7) emphasize the highly divergent nature of TFDaV.

\subsection{Infectivity and RNA silencing suppression assays}

$N$. benthamiana plants were PCR- and RCA-negative for the presence of TFDaV at either 20 or 45 days post-inoculation. Out of 23 inoculated apple and pear seedlings, 12 (eight apple cv. Gala, three apple cv. Fuji and one pear) were PCR-positive for TFDaV at 45 dpi (Suppl. Fig. S8), with one additional apple cv. Gala being PCRpositive only at $90 \mathrm{dpi}$ (Suppl. Fig. S8). Plants biolistically inoculated with the empty vector were all PCR-negative (Suppl. Fig. S8). These plants were also evaluated by RCA at 45, 90 and 180 dpi but there was no amplification of the expected fragment size, with the exception of one apple cv. Gala (plant \#4) at $180 \mathrm{dpi}$ (data not shown). This $3.4 \mathrm{~kb}$ amplified fragment was cloned and sequenced, confirming its identity as TFDaV.

Foliar symptoms were not observed in the inoculated plants. However, growth reduction was evident at both 90 and $180 \mathrm{dpi}$ (Fig. 3). Attempts to visualize viral particles by transmission electron microscopy from leaf tissue or petioles at 180 dpi were unsuccessful.

The putative CP and MP showed no local RNA silencing suppression activity in $N$. benthamiana leaves (Suppl. Fig. S9).

\section{Discussion}

Apple, pear and grapevines are clonally propagated by different forms of grafting. Unless quarantine measures are firmly established, the exchange of propagation materials between countries will virtually guarantee the spread of plant viruses and other grafttransmissible agents such as viroids and phytoplasmas. Indeed, plants displaying virus-like symptoms are frequently observed in Brazilian vineyards and orchards (Basso et al., 2014). However, due to mixed infections, variations in climatic and agronomic conditions, and intrinsic characteristics of these plants, it is difficult or even impossible to establish an association between field symptoms and a specific viral or subviral agent.

Until recently, viral detection strategies in plants focused on RNA viruses, for at least two reasons: (i) RNA viruses comprise the vast majority of plant viruses and include the most economically important ones; (ii) available methodologies had a strong sequence bias (e.g., use of degenerate primers in PCR-based assays) and therefore restricted the identification of divergent species. 

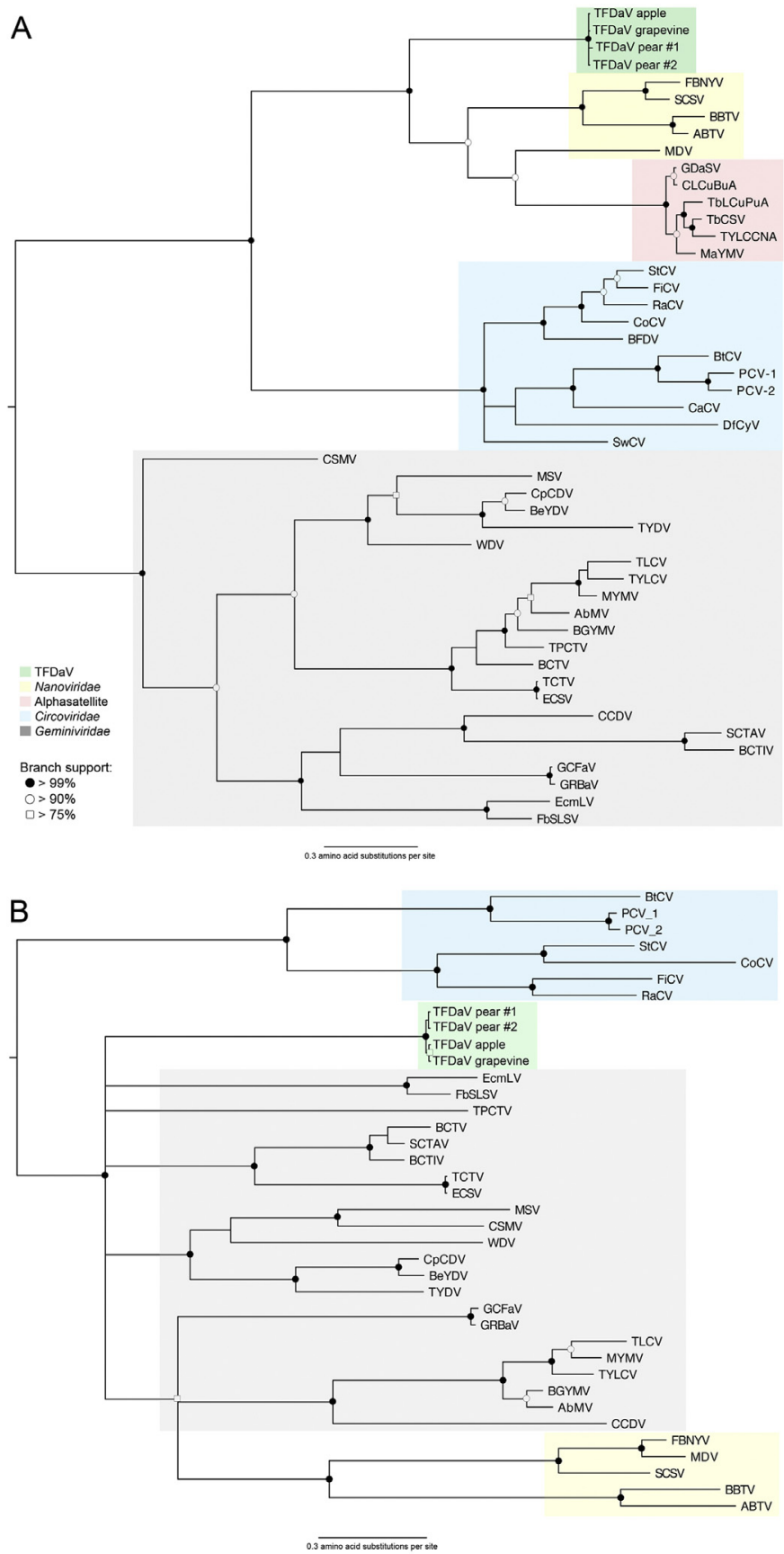

Fig. 2. Midpoint-rooted phylogenetic trees describing the evolutionary relationships between TFDaV isolates (apple, pear \#1, pear \#2 and grapevine) and circo-, nano-, geminiviruses and alphasatellites. A. Tree based on the deduced amino acid (aa) sequence of the replication-associated protein (Rep). B. Tree based on the deduced aa sequence of the coat protein (CP). Phylogenetic trees were constructed using Bayesian inference with MrBayes v.3.2 and BLOSUM as best-fit model. Branch length is proportional to the number of amino acid substitutions per site. GenBank accession numbers are available in Suppl. Table S2.

The development of sequence-unbiased methods such as RCA, and more recently the widespread availability of deep sequencing strategies, has unlocked the vault of DNA viruses with small genomes (mostly ssDNA viruses), indicating their presence in a massive scale in a variety of ecosystems (Labonte and Suttle, 2013; Rosario et al., 2012).

New ssDNA viruses have been discovered in various aquatic environments as well as in insects, plants and diatoms (Bernardo et al., 2013; Dayaram et al., 2014; Labonte and Suttle, 2013; Rosario

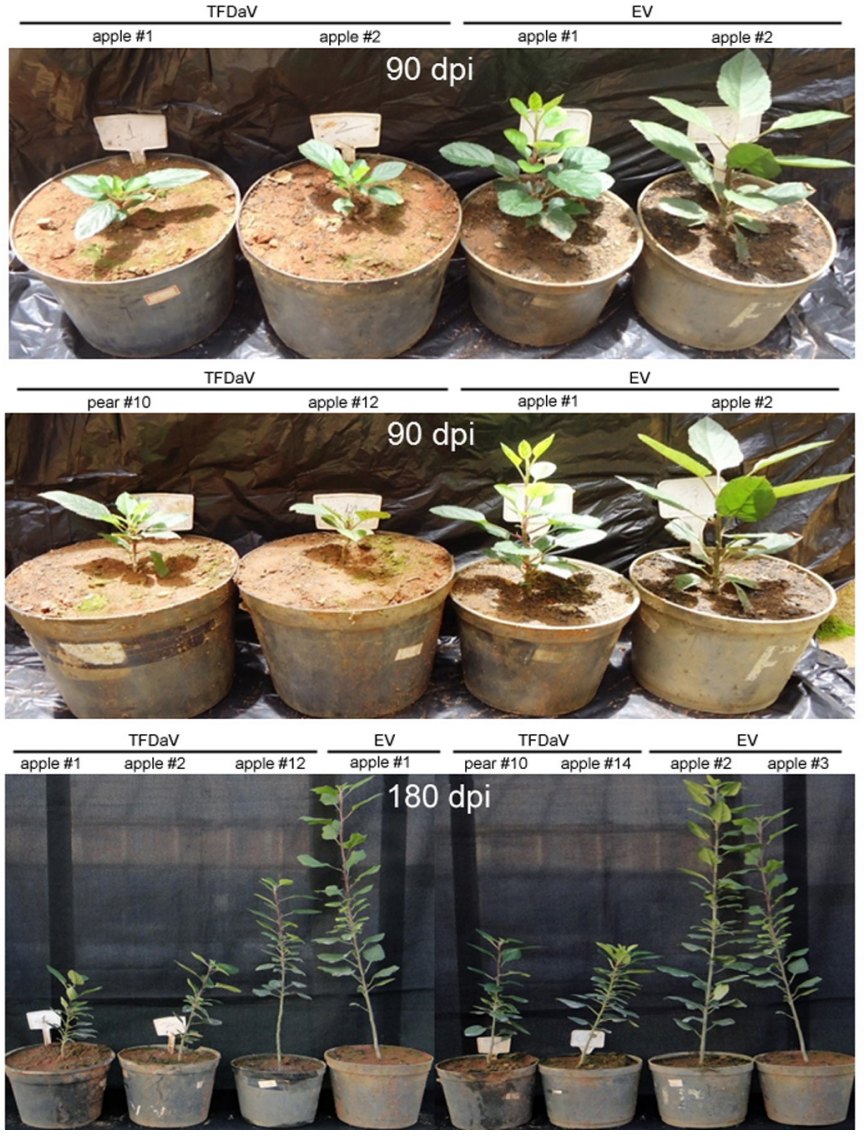

Fig. 3. Results of infectivity assay with TFDaV in apple and pear plants. Growth reduction observed in apple and pear plants following biolistic inoculation with cloned TFDaV, at 90 and 180 days post- inoculation (dpi). TFDaV, apple and pear plants inoculated with cloned TFDaV. EV, apple plants inoculated with the empty vector (negative control). Results of PCR-based viral detection in the inoculated plants are presented in Suppl. Fig. S8.

et al., 2009; Tomaru et al., 2013) uncovering the richness and diversity of this group of viruses. Recent reports of divergent geminiviruses in citrus and grapevine (Al-Rwahnih et al., 2013; Krenz et al., 2012; Loconsole et al., 2012; Poojari et al., 2013) indicated that perennial woody plants can also support infection by DNA viruses. Nevertheless, apple and pear had not yet been reported as hosts of ssDNA viruses.

TFDaV displays low sequence identities and is only distantly phylogenetically related to other circular ssDNA viruses, suggesting that it could be classified in a new genus or family. Circo-, nano- and geminiviruses present several traits in common, strongly suggesting a common origin (Gibbs and Weiller, 1999; Niagro et al., 1998). Metagenomic studies have revealed a wide diversity of ssDNA viruses in different biomes, many of which encode Rep proteins similar to those of gemini-, nano- and (most commonly) circoviruses (Labonte and Suttle, 2013; Rosario et al., 2012). However the origin(s) and evolutionary relationships amongst these three families of ssDNA viruses remain unknown. Interestingly, TFDaV shares common features with all three families (circoviruses: a monopartite genome, conserved domains in the Rep protein; circoand nanoviruses: the conserved nonanucleotide at the origin of replication; geminiviruses: conserved domains in the MP and $\mathrm{CP}$ ). Along with the absence of recombination events, which discards the possibility of TFDaV being an inter-family recombinant, these conserved features suggest that it could be a member of an ancestor group of circular ssDNA viruses. 
The Rep sequence and structural similarities suggest that TFDaV replicates through a rolling-circle mechanism in a similar manner to circo-, nano- and geminiviruses. Interestingly, the presence of Rb-binding motifs suggests that, like the Rep proteins of geminiviruses, the TFDaV Rep could be involved in cell cycle regulation (Gutierrez, 2000).

The presence of an importin $\alpha$-dependent NLS in the CP and its nuclear localization suggest that it can function also as a nuclear shuttle protein, facilitating the transport of viral DNA into and out of the nucleus (Fontes et al., 2004; Rojas et al., 2001). The putative MP contains a transmembrane domain commonly found in viral MPs, suggesting that it may act in viral cell-to-cell movement. None of the viral proteins tested showed local RNA silencing suppressor activity in $N$. benthamiana. However, since TFDaV infects woody, perennial plants, it is possible that its supressor protein(s) are unable to suppress RNA silencing in herbaceous plants.

Infectivity assays confirmed that TFDaV is capable of sistemically infecting apple and pear, causing growth reduction. The absence of foliar symptoms could be due to the relatively short (for a perennial, woody host) period of observation of $180 \mathrm{dpi}$. Latent periods of two or three years are not uncommon in such hosts (AlRwahnih et al., 2013; Basso et al., 2014; Loconsole et al., 2012). It is also possible that the original trees from which the virus was isolated were co-infected with other viruses or virus-like agents, and that infection by TFDaV does not induce foliar symptoms.

RCA and PCR-based assays were effective in detecting TFDaV in field plants. Nevertheless, viral incidence seems to be small (although our survey was limited). Additional studies are required to properly assess the incidence and the losses caused by TFDaV, as well as the possibility that it may have additional hosts.

\section{Acknowledgments}

This work was supported by the National Institute of Science and Technology in Plant-Pest Interactions, CAPES (doctoral fellowship to MFB), CNPq (grant 483607/2013-4 to FMZ) and FAPEMIG (grant APQ-00949-09 to FMZ).

\section{Appendix A. Supplementary data}

Supplementary data associated with this article can be found, in the online version, at http://dx.doi.org/10.1016/j.virusres.2015.07. 005

\section{References}

Al-Rwahnih, M., Daubert, S., Golino, D., Rowhani, A., 2009. Deep sequencing analysis of RNAs from a grapevine showing syrah decline symptoms reveals a multiple virus infection that includes a novel virus. Virology 387, 395-401.

Al-Rwahnih, M., Dave, A., Anderson, M.M., Rowhani, A., Uyemoto, J.K., Sudarshana, M.R., 2013. Association of a DNA virus with grapevines affected by red blotch disease in California. Phytopathology 103, 1069-1076.

Altschul, S.F., Gish, W., Miller, W., Myers, E.W., Lipman, D.J., 1990. Basic local alignment search tool. J. Mol. Biol. 215, 403-410.

Aragão, F.J.L., Barros, L.M.G., Brasileiro, A.C.M., Ribeiro, S.G., Smith, F.D., Sanford, J.C., Faria, J.C., Rech, E.L., 1996. Inheritance of foreign genes in transgenic bean (Phaseolus vulgaris L.) co-transformed via particle bombardment. Theor. Appl. Genet. 93, 142-150.

Basso, M.F., Fajardo, T.V.M., Eiras, M., Ayub, R.A., Nickel, O., 2010. Molecular detection and identification of virus associated with symptomatic and symptomless grapevines. Ciência Rural 40, 2249-2255.

Basso, M.F., Fajardo, T.V.M., Pio-Ribeiro, G., Eiras, M., Zerbini, F.M., 2014. Avanços e perspectivas no estudo das doenças virais e subvirais em videira com ênfase na realidade brasileira. Rev. Anu. Pat. Plant 22, 160-207.

Bernardo, P., Golden, M., Akram, M., Naimuddin, Nadarajan, N., Fernandez, E., Granier, M., Rebelo, A.G., Peterschmitt, M., Martin, D.P., Roumagnac, P., 2013. Identification and characterisation of a highly divergent geminivirus: evolutionary and taxonomic implications. Virus Res. 177, 35-45.

Dayaram, A., Galatowitsch, M., Harding, J.S., Arguello-Astorga, G.R., Varsani, A., 2014. Novel circular DNA viruses identified in Procordulia grayi and Xanthocnemis zealandica larvae using metagenomic approaches. Infect. Genet. Evol. 22, 134-141.
Edgar, R.C., 2004. MUSCLE: a multiple sequence alignment method with reduced time and space complexity. BMC Bioinform. 5, 1-19.

Fontes, E.P.B., Santos, A.A., Luz, D.F., Waclawovsky, A.J., Chory, J., 2004. The geminivirus nuclear shuttle protein is a virulence factor that suppresses transmembrane receptor kinase activity. Genes Dev. 18, 2545-2556.

Gibbs, M.J., Weiller, G.F., 1999. Evidence that a plant virus switched hosts to infect a vertebrate and then recombined with a vertebrate-infecting virus. Proc. Natl. Acad. Sci. U. S. A. 96, 8022-8027.

Gutierrez, C., 2000. Geminiviruses and the plant cell cycle. Plant Mol. Biol. 43, $763-772$.

Hadidi, A., Barba, M., 2011. Economic impact of pome and stoone fruit viruses and viroids. In: Hadidi, A., Barba, M., Candresse, T., Jelkmann, W. (Eds.), Virus and Virus-Like Diseases of Pome and Stone Fruits. APS Press, St. Paul, MN, p. 428.

Inoue-Nagata, A.K., Albuquerque, L.C., Rocha, W.B., Nagata, T., 2004. A simple method for cloning the complete begomovirus genome using the bacteriophage phi 29 DNA polymerase. J. Virol. Met. 116, 209-211.

Johansen, L.K., Carrington, J.C., 2001. Silencing on the spot. Induction and suppression of RNA silencing in the agrobacterium-mediated transient expression system. Plant Physiol. 126, 930-938.

Kosugi, S., Hasebe, M., Tomita, M., Yanagawa, H., 2009. Systematic identification of yeast cell cycle-dependent nucleocytoplasmic shuttling proteins by prediction of composite motifs. Proc. Natl. Acad. Sci. U. S. A. 106, 10171-10176.

Krenz, B., Thompson, J.R., Fuchs, M., Perry, K.L., 2012. Complete genome sequence of a new circular DNA virus from grapevine. J. Virol. 86, 7715.

Labonte, J.M., Suttle, C.A., 2013. Previously unknown and highly divergent ssDNA viruses populate the oceans. ISME J. 7, 2169-2177.

Lefeuvre, P., Lett, J.M., Varsani, A., Martin, D.P., 2009. Widely conserved recombination patterns among single-stranded DNA viruses. J. Virol., 2697-2707

Letunic, I., Doerks, T., Bork, P., 2012. SMART 7: recent updates to the protein domain annotation resource. Nucleic Acids Res. 40, D302-D305.

Loconsole, G., Saldarelli, P., Doddapaneni, H., Savino, V., Martelli, G.P., Saponari, M. 2012. Identification of a single-stranded DNA virus associated with citrus chlorotic dwarf disease, a new member in the family Geminiviridae. Virology 43, 162-172.

Lodhi, M.A., Ye, G.-N., Weeden, N.F., Reisch, B.I., 1994. A simple and efficient method for DNA extraction from grapevine cultivars, Vitis species and Ampelopsis. Plant Mol. Biol. Rep. 12, 6-13.

Marchler-Bauer, A., Lu, S.N., Anderson, J.B., Chitsaz, F., Derbyshire, M.K. DeWeese-Scott, C., Fong, J.H., Geer, L.Y., Geer, R.C., Gonzales, N.R., Gwadz, M. Hurwitz, D.I., Jackson, J.D., Ke, Z.X., Lanczycki, C.J., Lu, F., Marchler, G.H., Mullokandov, M., Omelchenko, M.V., Robertson, C.L., Song, J.S., Thanki, N., Yamashita, R.A., Zhang, D.C., Zhang, N.G., Zheng, C.J., Bryant, S.H., 2011. CDD: a conserved domain database for the functional annotation of proteins. Nucleic Acids Res. 39, D225-D229.

Martelli, G.P., 2012. Grapevine virology highlights 2010-12. Extended abstracts. 17 th Meeting of International Council of Viruses and Virus Diseases of Grapevine, 13-31.

Martin, D.P., Biagini, P., Lefeuvre, P., Golden, M., Roumagnac, P., Varsani, A., 2011. Recombination in eukaryotic single stranded DNA viruses. Viruses 3. 1699-1738.

Martin, D.P., Lemey, P., Lott, M., Moulton, V., Posada, D., Lefeuvre, P., 2010. RDP3: a flexible and fast computer program for analyzing recombination. Bioinformatics 26, 2462-2463.

McVean, G., Awadalla, P., Fearnhead, P., 2002. A coalescent-based method for detecting and estimating recombination from gene sequences. Genetics 160, 1231-1241

Moller, S., Croning, M.D.R., Apweiler, R., 2001. Evaluation of methods for the prediction of membrane spanning regions. Bioinformatics 17, 646-653.

Muhire, B.M., Varsani, A., Martin, D.P., 2014. SDT: a virus classification tool based on pairwise sequence alignment and identity calculation. PLoS One 9, e108277.

Niagro, F.D., Forsthoefel, A.N., Lawther, R.P., Kamalanathan, L., Ritchie, B.W., Latimer, K.S., Lukert, P.D., 1998. Beak and feather disease virus and porcine circovirus genomes: intermediates between the geminiviruses and plant circoviruses. Arch. Virol. 143, 1723-1744.

Poojari, S., Alabi, O.J., Fofanov, V.Y., Naidu, R.A., 2013. A leafhopper-transmissible DNA virus with novel evolutionary lineage in the family Geminiviridae implicated in grapevine redleaf disease by next-generation sequencing. PLoS One 8, e64194.

Rojas, M.R., Gilbertson, R.L., Russell, D.R., Maxwell, D.P., 1993. Use of degenerate primers in the polymerase chain reaction to detect whitefly-transmitted geminiviruses. Plant Dis. 77, 340-347.

Rojas, M.R., Jiang, H., Salati, R., Xoconostle-Cazares, B., Sudarshana, M.R., Lucas, W.J., Gilbertson, R.L., 2001. Functional analysis of proteins involved in movement of the, monopartite begomovirus, tomato yellow leaf curl virus. Virology 291, 110-125.

Ronquist, F., Huelsenbeck, J.P., 2003. MrBayes 3: Bayesian phylogenetic inference under mixed modelsMrBayes 3: Bayesian phylogenetic inference under mixed models. Bioinformatics 19, 1572-1574.

Rosario, K., Duffy, S., Breitbart, M., 2009. Diverse circovirus-like genome architectures revealed by environmental metagenomics. J. Gen. Virol. 90 2418-2424

Rosario, K., Duffy, S., Breitbart, M., 2012. A field guide to eukaryotic circular single-stranded DNA viruses: insights gained from metagenomics. Arch. Virol. $157,1851-1871$. 
Rowhani, A., Uyemoto, J.K., Golino, D.A., Martelli, G.P., 2005. Pathogen testing and certification of Vitis and Prunus species. Annu. Rev. Phytopath. 43, 261-278.

Tamura, K., Stecher, G., Peterson, D., Filipski, A., Kumar, S., 2013. MEGA6: molecular evolutionary genetics analysis version 6.0. Mol. Biol. Evol. 30, 2725-2729.
Tomaru, Y., Toyoda, K., Suzuki, H., Nagumo, T., Kimura, K., Takao, Y., 2013. New single-stranded DNA virus with a unique genomic structure that infects marine diatom Chaetoceros setoensis. Sci. Rep. 3, 3337.

Wang, L., Brown, S.J., 2006. BindN: a web-based tool for efficient prediction of DNA and RNA binding sites in amino acid sequences. Nucleic Acids Res. 34, W243-W248 